\title{
A Perspective of the Segregation Process
}

\author{
Taneomi HARADA, Shuji OWADA \\ and Akskadi DJOHARI
}

\begin{abstract}
The segregation process is an effective method for treating oxide ores containing metals such as antimony, bismuth, cobalt, copper, gold, lead, nickel, palladium, silver and tin which form volatile chlorides or oxychlorides.

In the process an ore is heated, together with a chloride and carbon, to some optimum temperature. The metal in the ore is chloridized and volatilized, and is then deposited in a metallic state on the carbon surfaces. The metal can then be concentrated cheaply by a subsequent screening, magnetic separation or flotation prior to smelting.

In this paper, 1) reaction mechanism of the segregation (generation of hydrogen chloride gas; formation and volatilization of metal chlorides; precipitation of metals on carbon surfaces), 2) segregation of oxide copper ores (history of development; commercial operation at Katanga Mine in Peru), 3) segregation of oxide nickei ores (history of studies; test operation by the MINPRO-PAMCO process), and 4) segregation of manganese nodules (trend of studies; a study by Parekh, Jensen and Goldberger; a study by the authors) are outlined.
\end{abstract}

\section{1. ま か がき}

セグレゲーション法 (Segregation process) は, “塩化物 と還元剤の存在のもとで鉱石をばい焼し，酸化金属鉱物 などを還元した後，浮選などにより金属を分離，回収す る方法”と定義されている1。この方法については，今 泉常正東大名誉教授が，かつて本誌に優れた総説2)を発 表しておられる。当時は，米国 Lake shore 鉱山で1960 年に本法を適用した直後であり，ほかにもぺルー Berenguela 鉱山やモリタニア Akjoujt 鉱山で試験操業が 開始されていて，世界的にセグレゲーション法への関心 が高まりをみせていた時期であった。対象鉱石はいずれ も酸化銅鉱であった。

その後セグレゲーション法の熱力学的考察の進歩3) や わが国の三井金属鉱業によるペル一国 Katanga 鉱山(酸 化銅鉱）での本法による操業開始（1973年）4７）などが あり，また Svensson によるいわゆるメカニカルキルン

* 工博 早稲田大学教授 理工学部資源工学科

** 工博 早稲田大学助教授 理工学部資源工学科

*** 早稲田大学大学院 理工学研究科博士浬程 平成元年 12 月 28 日受理
の発明 $(1975)^{8)}$ により, 酸化ニッケル鉱へのセグレゲー ション法の導入も, 実現する日が近いと期待されている9,10)。 最近は, マンガンノジュールヘの本法適用の可能性を

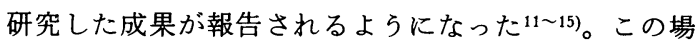
合, 回収対象となる金属は銅, ニッケルおよびュバルト である。

セグレゲーション法は, 揮発性塩化物またはオキシ塩 化物を形成する金属に適用できるから，上記のほかアン チモン, ビスマス, 金, 銀, パラジウム, 鉛, 錫などを 含む鉱石の処理に応用の可能性がある。これに関する研

表 1 ×カニカルキルンの仕様（石井帛による）

\begin{tabular}{|c|c|}
\hline $\begin{array}{l}\text { メカカルキルン } \\
\text { の寸法 }\end{array}$ & $\begin{array}{ll}\text { 内径 } \times \text { 内長 } & 3.5 \mathrm{~m} \phi \times 3.8 \mathrm{~mL} \\
\text { 外径 } \times \text { 外長 } & 4.5 \mathrm{~m} \phi \times 5.0 \mathrm{~mL}\end{array}$ \\
\hline ライニング & $\begin{array}{l}\text { 電鋳煉瓦とシャモット質耐火断 } \\
\text { 熱煉瓦の二層張り }\end{array}$ \\
\hline$モ-タ$ & $850 \mathrm{~kW}$ \\
\hline 回 転 数 & $\begin{array}{l}0 \sim 14 \mathrm{rpm} \\
\text { (臨界回転数の0〜62\%) }\end{array}$ \\
\hline 粉砕媒体 & $60 \mathrm{~mm} \phi$ アルミナボール : $33 \mathrm{t}$ \\
\hline
\end{tabular}




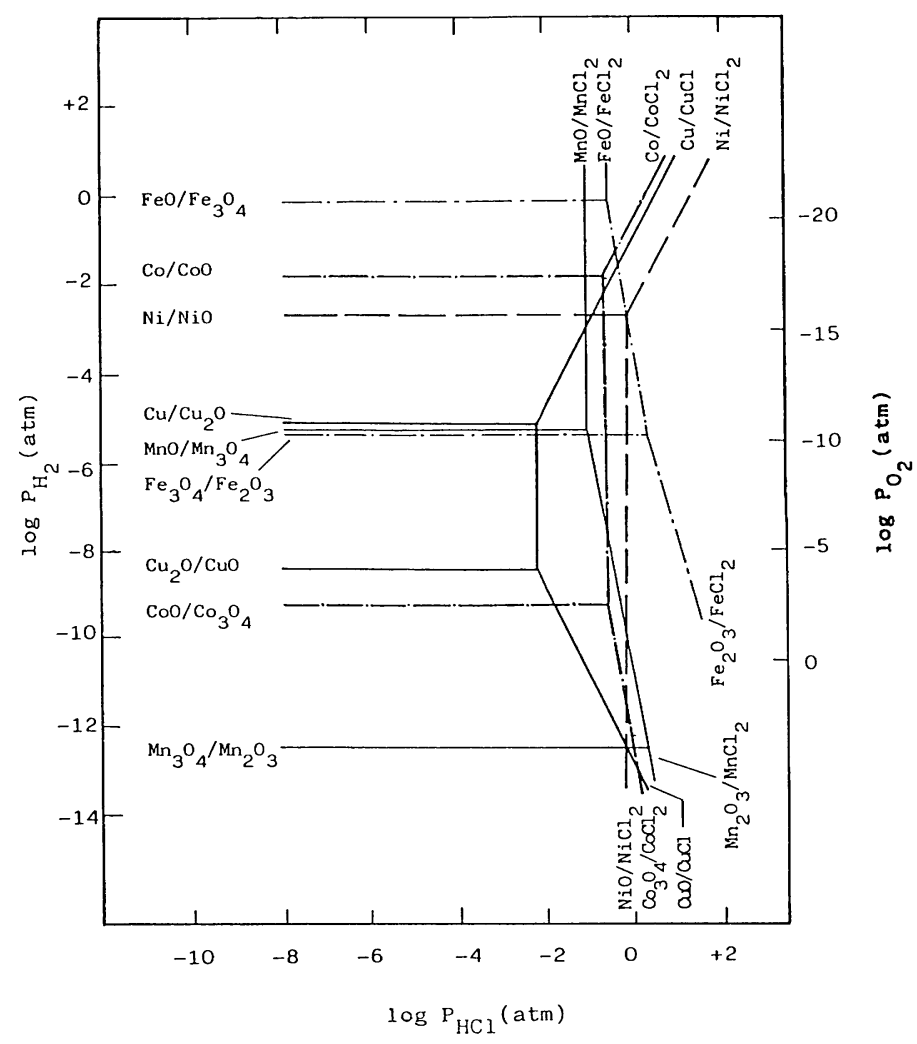

図 $1750^{\circ} \mathrm{C}$ 水蒸気圧 $0.3 \mathrm{~atm}$ における $\mathrm{Cu} / \mathrm{Ni} / \mathrm{Co} / \mathrm{Fe} / \mathrm{Mn}-\mathrm{H}_{2} / \mathrm{HCl}$ 系の平衡状態図 (Iwasaki3) による)

究も今後大いに進展するものと思われる。

\section{2. セグレゲーション反応の機構}

冒頭の定義をもら少し肉づけすると，セグレゲーショ ン法は，炭素の存在下で鉱石を塩化物とともに加熱し， 金属酸化物を塩化，揮発させて炭素表面上に吸着させた
のち，それを炭素と水蒸気との反応で発生した水素によ り還元する方法といえる。Rey ${ }^{16)}$ は，その基本的な反応 として次の三つを挙げている。

1）塩化水素ガスの発生

2）金属成分の塩化および金属塩化物の蒸発

3）炭素表面上への金属相の析出
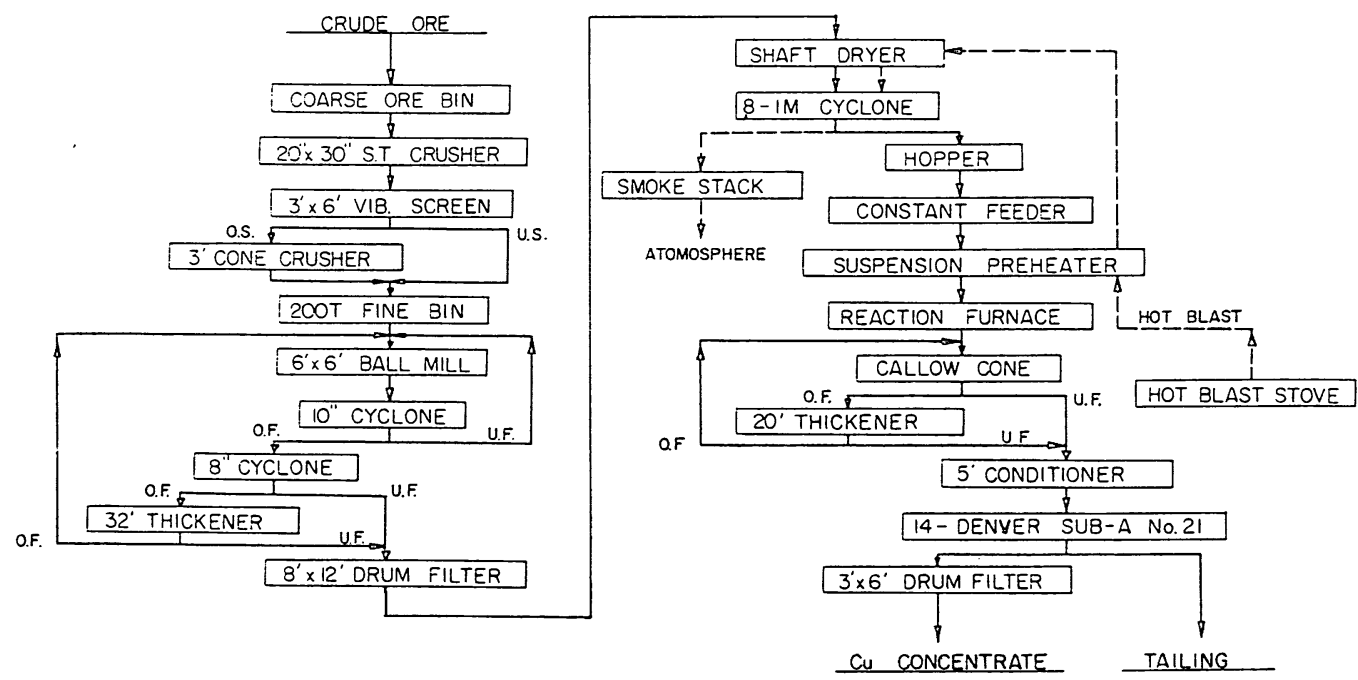

図 2 ペルーKatanga 鉱山鉱石処理系統図 (Kaneko ${ }^{5)}$ によ 
表 2 MINPRO-PAMCO 法による磁選試験成績の例 (石井9) による)

\begin{tabular}{|c|c|c|c|c|c|c|}
\hline & \multirow{2}{*}{$\begin{array}{c}\text { 重量比 } \\
\%\end{array}$} & \multicolumn{2}{|l|}{ 分 } & \multicolumn{2}{|c|}{ 分 布 率 } \\
\hline & & & $\mathrm{Ni} \%$ & $\mathrm{Fe} \%$ & $\mathrm{Ni} \%$ & $\mathrm{Fe} \%$ \\
\hline \multicolumn{2}{|c|}{ ドラム磁選機の給鉱 } & 100.0 & 2.47 & 13.7 & 97.9 & 94.5 \\
\hline "I & 精鉱 & 4.0 & 55.4 & 27.4 & 87.7 & 7.6 \\
\hline "1 & 尾鉱 & 96.0 & 0.27 & 13.1 & 10.2 & 86.9 \\
\hline \multicolumn{2}{|c|}{ ジョーンズ磁選機精鉱 } & 8.1 & 1.38 & 13.9 & 4.4 & 7.8 \\
\hline " & 尾鉱 & 87.9 & 0.16 & 13.0 & 5.8 & 79.1 \\
\hline
\end{tabular}

\section{1 塩化水素ガスの発生}

セグレゲーション焙焼において，塩化剤となるのは水 蒸気と塩化物（ $\mathrm{NaCl}, \mathrm{CaCl}_{2}$ など）との反応によって発 生する塩化水素ガスである。その発生量は, この反応で 生成する酸化物（ $\mathrm{Na}_{2} \mathrm{O}, \mathrm{CaO}$ など） と，鉱石中の酸性 成分である石英や粘土鉣物との反応に影響される。その 反応式を示せば次のよらである。

$\mathrm{CaCl}_{2}+\mathrm{SiO}_{2}+\mathrm{H}_{2} \mathrm{O} \rightarrow \mathrm{CaSiO}_{3}+2 \mathrm{HCl}$

\section{2 金属成分の塩化および金属塩化物の蒸発}

鉱石中に存在する $\mathrm{Cu}, \mathrm{Ni}$ および $\mathrm{Co}$ の酸化物は, 発 生した塩化水素と次式のように反応して金属塩化物の蒸 気を形成する。

$\mathrm{Cu}_{2} \mathrm{O}(\mathrm{s})+2 \mathrm{HCl}(\mathrm{g}) \rightarrow \frac{2}{3} \mathrm{Cu}_{3} \mathrm{Cl}_{3}(\mathrm{~g})+\mathrm{H}_{2} \mathrm{O}(\mathrm{g})$

$\mathrm{NiO}(\mathrm{s})+2 \mathrm{HCl}(\mathrm{g}) \rightarrow \mathrm{NiCl}_{2}(\mathrm{~g})+\mathrm{H}_{2} \mathrm{O}(\mathrm{g})$
$\mathrm{CoO}(\mathrm{s})+2 \mathrm{HCl}(\mathrm{g}) \rightarrow \mathrm{CoCl}_{2}(\mathrm{~g})+\mathrm{H}_{2} \mathrm{O}(\mathrm{g})$

2.3 炭素表面上への金属相の析出

金属塩化物の蒸気は炭素表面に吸着し，そこで，炭素 と水蒸気との反応で発生した水素ガスにより還元が進む と推測される。水素の発生および各金属塩化物の還元は, 次式のよ5に進行するものと考えられる。

$\mathrm{H}_{2} \mathrm{O}(\mathrm{g})+\mathrm{C}(\mathrm{s}) \rightarrow \mathrm{H}_{2}(\mathrm{~g})+\mathrm{CO}(\mathrm{g})$

$\frac{2}{3} \mathrm{Cu}_{3} \mathrm{Cl}_{3}(\mathrm{~g})+\mathrm{H}_{2}(\mathrm{~g}) \rightarrow 2 \mathrm{Cu}(\mathrm{s})+2 \mathrm{HCl}(\mathrm{g})$

$\mathrm{NiCl}_{2}(\mathrm{~g})+\mathrm{H}_{2}(\mathrm{~g}) \rightarrow \mathrm{Ni}(\mathrm{s})+2 \mathrm{HCl}(\mathrm{g})$

$\mathrm{CoCl}_{2}(\mathrm{~g})+\mathrm{H}_{2}(\mathrm{~g}) \rightarrow \mathrm{Co}(\mathrm{s})+2 \mathrm{HCl}(\mathrm{g})$

図 1 に, $750^{\circ} \mathrm{C}$ 水蒸気圧 $0.3 \mathrm{~atm}$ に打ける $\mathrm{Cu} / \mathrm{Ni} / \mathrm{Co} / \mathrm{Fe} / \mathrm{Mn}-\mathrm{H}_{2} / \mathrm{HCl}$ 系の平衡状態図を示す。図中, 五つの金属元素のうち, $\mathrm{Cu}$ が最も容易に塩化，還元さ れることがわかる。Coは Ni と比べ塩化されやすいが,

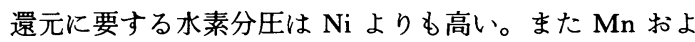
び $\mathrm{Fe}$ は, $\mathrm{MnO}, \mathrm{FeO}$ の状態では $\mathrm{Ni}$ に比べて若干塩化 されやすいが, 還元に要する水素分圧は非常に高い。こ れらのことから, $\mathrm{Mn}, \mathrm{Fe}$ が共存するマンガンノジュー ルの場合にも， Cu, Ni および Coを選択的に還元しらる ことが示唆される。

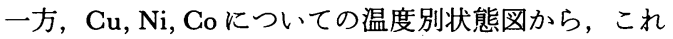
ら元素の塩化および還元のための塩化水素と水素の分圧 は，温度の上昇とともに増大することが知られている3゙。 なお, 系内の水素分圧が過剰または過度の還元雰囲気

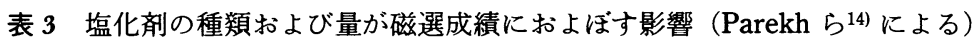

\begin{tabular}{|c|c|c|c|c|c|c|c|}
\hline \multirow{2}{*}{$\begin{array}{l}\text { 試験 } \\
\text { 番号 }\end{array}$} & \multirow{2}{*}{$\begin{array}{c}\text { 塩化刘の種類 } \\
\text { および量 }\end{array}$} & \multirow{2}{*}{ 産物 } & \multicolumn{2}{|c|}{ 分 析 值 } & \multicolumn{3}{|c|}{ 分 布 } \\
\hline & & & $\% \mathrm{Ni}$ & $\% \mathrm{Cu}$ & $\% \mathrm{Ni}$ & & $\% \mathrm{Cu}$ \\
\hline \multirow[t]{2}{*}{ A } & $\mathrm{CaCO}_{3}(12 \mathrm{wt} \%)$ & 精鉱 & 12.30 & 6.80 & 43.3 & & 31.1 \\
\hline & $\mathrm{NaCl}(14 \mathrm{wt} \%)$ & 尾鉱 & 0.60 & 0.85 & 17.9 & & 32.9 \\
\hline \multirow[t]{2}{*}{ B } & $\mathrm{Ca}(\mathrm{OH})_{2}(10 \mathrm{wt} \%)$ & 精鉱 & 12.10 & 7.00 & 46.7 & & 35.9 \\
\hline & $\mathrm{NaCl}(14 \mathrm{wt} \%)$ & 尾鉱 & 0.49 & 0.77 & 12.6 & & 26.2 \\
\hline \multirow[t]{2}{*}{$\mathrm{C}$} & $\mathrm{CaCl}_{2}(15 \mathrm{wt} \%)$ & 精鉱 & 12.68 & 7.50 & 59.4 & & 43.6 \\
\hline & & 尾鉣 & 0.70 & 0.98 & 23.6 & & 41.0 \\
\hline \multirow[t]{2}{*}{$\mathrm{D}$} & $\mathrm{CaO}(7.5 \mathrm{wt} \%)$ & 精鉱 & 5.07 & 2.55 & 30.1 & & 21.0 \\
\hline & $\mathrm{NaCl}(14 \mathrm{wt} \%)$ & 尾鉱 & 1.17 & 1.25 & 30.1 & & 44.6 \\
\hline \multirow[t]{2}{*}{$\mathrm{E}$} & $\mathrm{CaSO}_{4}(19 \mathrm{wt} \%)$ & 精鉱 & 2.87 & 1.66 & 4.2 & . & 3.4 \\
\hline & $\mathrm{NaCl}(13 \mathrm{wt} \%)$ & 尾鉱 & 2.03 & 1.45 & 66.4 & & 88.3 \\
\hline
\end{tabular}

表 4 セグレゲーション産物の浮選および磁選結果の比較

\begin{tabular}{|c|c|c|c|c|c|c|c|c|}
\hline \multirow{2}{*}{$\begin{array}{l}\text { セグレゲーション } \\
\text { 産物 }\end{array}$} & \multirow{2}{*}{ 重量\% } & \multirow{2}{*}{ 種 別 } & \multicolumn{3}{|c|}{ 浮 選 } & \multicolumn{3}{|c|}{ 磁選 } \\
\hline & & & $\mathrm{Cu}$ & $\mathrm{Ni}$ & Co & $\mathrm{Cu}$ & $\mathrm{Ni}$ & Co \\
\hline \multirow{2}{*}{$>212 \mu \mathrm{m}$} & \multirow{2}{*}{$18-22$} & 実 収 率\% & 82.24 & 82.42 & 82.37 & 95.76 & 97.36 & 96.72 \\
\hline & & 精鉱品位\% & 5.70 & 5.93 & 0.87 & 12.23 & 12.81 & 1.60 \\
\hline \multirow{2}{*}{$<212 \mu \mathrm{m}$} & \multirow{2}{*}{$78-82$} & 実 収 率\% & 30.11 & 26.22 & 21.57 & 75.34 & 65.32 & 63.04 \\
\hline & & 精鉱品位\% & 1.88 & 2.57 & 0.48 & 0.43 & 0.53 & 0.24 \\
\hline
\end{tabular}


となれば，金属酸化物はそのまま金属にまで睘元されて 炭素上に析出せず，鉱石中に微細な形で散在するように なるので効果的なセグレゲーションが期待できなくな る。このため, 炬内の水素分圧を適切に調整することは 極めて重要である。

\section{3. 酸化銅鉱のセグレゲーション}

\section{1 発展の経過}

（1）セグレゲーション法の発明19) 1923年，浮選法の パイオニアである British Minerals Separation 社は, チ リーの Sagasca 鉱の処理法を研究した。そのアイディア は Perkins 法を用いるといらもので, 同法では銅は金属 相に還元され，そしてアンモニアで浸出される。還元の ため, ガスの代りに固体炭素を用い $750^{\circ} \mathrm{C}$ に加熱した

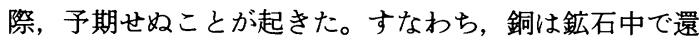
元せず，炭素粒子上に外皮や沈殿物となって付着した。 この現象は鉱石中に少量の $\mathrm{NaCl}$ が存在したため起こっ たものである。結晶質で輝く銅は, 浸出法よりも操業が 簡単な浮選法で容易に回収される。この方法は, 難処理 鉱の二つの欠点を克服しうるので,大きな関心を集めた。 すなわち,クリソコラのよらな珪酸塩から銅が回収でき, また脈石中に種々の形体で散らばる銅分も同様に回収で きる。銅が鉱石粒子から炭素まで移送されることにちな み，本法はセグレゲーション法と命名された。

(2) コンゴ Katanga 鉱山での操業19) Union Minière du Haut-Katanga 社は難処理鉱の大鉱体を所有していたの でほほどなくセグリゲーション法に興味を寄せた。1927 年に研究を開始したが，これを担当したのが Rey ${ }^{19)}$ で ある。パイロットプラント $(1 \mathrm{t} / 24 \mathrm{~h})$ テストを経て， 1931年には $350 \mathrm{t} /$ 日 の工場が完成した。しかし折悪しく 世界的不景気のあおりを受け，当初から大幅な減産を余 儀なくされた。また操業も不安定で, 機械的故障に兴ま され，間もなく工場は閉鎖された。

(3) ローデシア Alaska 鉱山での操業19) 1931年に多段 ハース炉により操業が開始された。上方ハースで加熱が, 下方ハースでセグレゲーションが行なわれた。 $3,500 \mathrm{t}$ の鉱石が成功裡に処理されたが，カタンガ鉱山における と同様，不況のために工場は閉鎖された。

(4) モーリタニア Akjoujt 鉱山での操業 ${ }^{19}$

a. 第 1 期（1956年～1959年）この期間は, フラン ス人技師が操業に参画した。当初 $25 \mathrm{t}$ /日 のパイロット プラントが計画されたが, 実際にはその 3 倍の規模のも

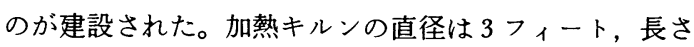
は80フィートで, 燃料油を熱源とした。反応炉は非常に コンパクトであった。セグレゲートされた鉱石は水で急 冷後浮選工程へ送られた。1958年から59年にかけての10 か月連続操業期間中に, このプラントは $2,500 \mathrm{t}$ の鉱石

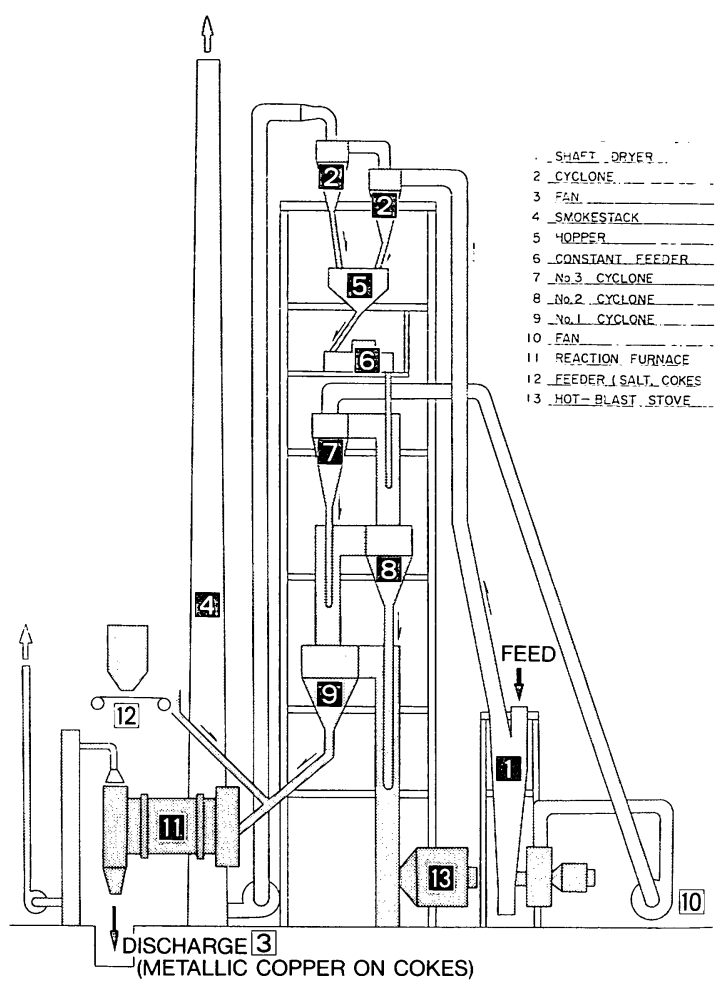

図 3 ペルーKatanga 鉱山セグレゲーション設備 (Kaneko') による)

を処理した。しかしこのプラントは，パイロットプラン トとしては過大で，改造工事をするには経費が部みすぎ るほか, 日常操業も割高のため長続きしなかったといら。

b. 第 2 期（1971年～1975年） この期間は，英国人 技師が操業に参画した。まず第 1 期に行なわれたプロセ スを改良し,これを TORCO (Treatment of Refractory Copper Ores) 法とよんだ。

TORCO 法において，加熱は流動層中で行なわれる。 熱せられた鉱石は，反応炉中にオーバフローし，炬から 排出する前の数分間, 半流動状態に保たれる。

小規模パイロット設備による Akjoujt 鉱の予備試験結 果は，実収率 $87.5 \%$ といら好成績であったので， 4,000 t/日の型工場が建設され，1971年から操業に入った。 1972年から 75 年までの間に鉱量の $40 \%$ が処理されたが, 操業不調のためにその大半が浪費されたといら。1975年, モーリタニア政府はこの工場を国有化し，生産規模を縮 小した。

(5) 米国 Lake Shore 鉱山での操業19) 米国鉱山局が開 発した 1 段処理方式に基づきこの鉱山では，天然がスで 加熱する小形工場が1960年に操業を始め，好成績のもと に 6 か月間稼働した。この方法の難点は, 炬の処理能力 が非常に小さいこと $(7 \sim 8 \mathrm{t} / \mathrm{h})$ と, とくに清浄な天然ガ スの代りに燃料油を用いた場合，銅鉄の炬体寿命が不確 


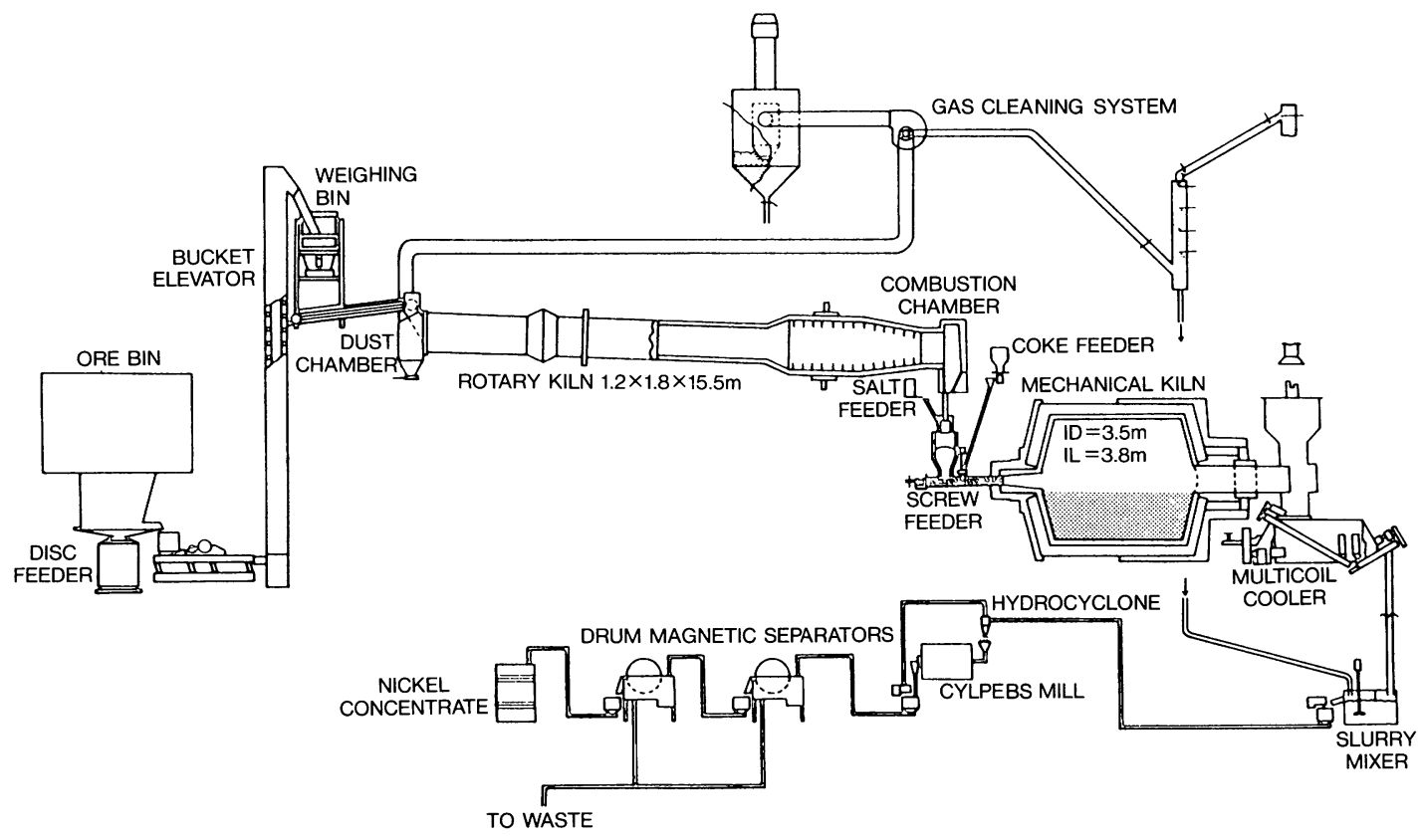

図 4 MINPRO-PAMCO 法試験操業におけるロータリーキルンおよびメカニカルキルン配置図 (Ericson ら10)による)

かとなることであった。

1 段処理方式の単純性を生かし，1963年鉱山局は，厚 い鉱石層を用いた直接燃焼キルンにより同様の操業を試 みた。この方法は Homestake Mining 社で試験され，の ちに大形の200フィートキルンの規模で, Lake Shore 鉱 山で操業に移された。鉱石中のダストの含有が問題点で あり，ガス流による塩化物と塩酸の流出を補らため，食 塩の使用の増大が余儀なくされた。この工場は，のちに 豊富な硫化物鉱石の利用が可能となった段階で閉鎖され た。この方法はおそらく、フィードをペレタイジングす ることで完璧なものとなったであろうし，単純かつ有効 なセグレゲーション法となる可能性をもつものといわれる。 (6) ペルー Berenguela 鉱山での試験操業2) 英国系の Lampa Mining 社は,この鉱山の大量の低品位銅鉱を対 象としてセグレゲーション法の採用を企図し, 同所に 1 $\mathrm{t} / \mathrm{h}$ の試験工場を建設した。粗鉱品位は不定で, $1 \sim 3 \% \mathrm{Cu}, 60 \sim 15,000 \mathrm{~g} / \mathrm{t} \mathrm{Ag}$ の範囲におよぶ。

$50 \mathrm{t}$ 鉱舎に貯えた粉砕鉱石は, 一定量の水をスプレー によって加え，ロータリーフィーダでパンペレタイザに 装入する。ペレットは立型焼鉱炉に装入される。ペレッ 卜は固定炬床上に充填され，反応が終ると耐熱銅の押し 棒で，順次下の水冷タンクに焼鉱を落してゆく。この炉 の所要熱量は焼鉱 $1 \mathrm{t}$ 当り $700,000 \mathrm{Kcal}$ (net) である。

焼鉱ペレットは水冷タンクに落ちると砕解して, 小片 を含む泥状になる。これをボールミルで軽く粉砕し，浮 選により金属銅を回収する。精鉱品位は通常
$40 \sim 60 \% \mathrm{Cu}, 0.6 \sim 1.5 \% \mathrm{Ag}$ である。銅実収率は $80 \sim 85 \%$ ， 銀実収率は70〜75\%である。この試験工場での操業成績 を基礎として，100t/日 および $300 \mathrm{t} /$ 日 のセグレゲーシ

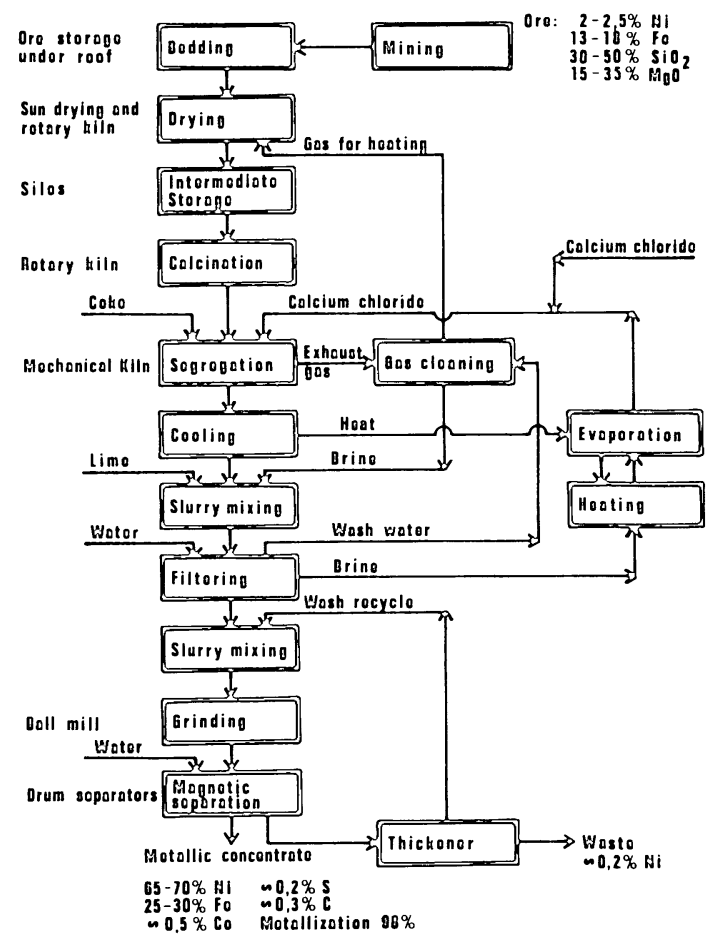

図 5 MINPRO-PAMCO 法の工業化のために提案され

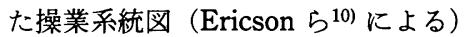


ョン工場の操業費 (1960年 9 月現在)が試算されている。 (7) ペルー Katanga 鉱山での操業7,19) 三井金属鉱業 は，多年基礎研究に取り組んだ末，セグレゲーション法 の改良技術を確立し工業化に成功した。すなわ1973年, ペルー Katanga 鉱山で工場の操業を開始し，1982年末 対象鉱石が枯渴するまで操業を続けた。セグレゲーショ ン法の最大の問題点は，熱源を持たない鉱石を $800^{\circ} \mathrm{C}$ 前後まで加熱することであり，この熱効率の良否が本法 の経済性を左右する。三井方式は排ガス温度 $250^{\circ} \mathrm{C}$ で, 前述の TORCO 法のそれよりも低く, 熱効率の点で非 常に優れているといわれる。また, TORCO 法が直接 加熱方式であるため燃料の種類が限定されるが，三井方 式は間接加熱であるため燃料の種頢を問わないという長 所が指摘されている。

三井方式の操業の詳細を次節に示す。

3.2 ペルーKatanga 鉱山における操業の実際5,7)

（1）概説 Katanga 鉱山は，三井金属鉱業（株）の系 列会社であるカタンガ鉱業（株）により運営された。鉱 山はペルー南部 Cuzco 県に位置し, 標高は 4,000 m に達 する。鉱床は古生代の石灰岩層に花崗閃緑岩が迸入して 生成された接触鉱床である。鉱床深部では局部的に黄銅 鉱, 輝銅鉱, 斑銅鉱なども認められるが, 量的にはごく 僅かであり，主たる稼行対象は孔雀石，珪孔雀石等の緑 色銅鉱物である。脈石としては石英，方解石，灰鉄ざく ろ石および少量の雲母頑を伴う。鉱体が丘の斜面に露出 しているので, 採掘は階段式露天掘りによる。

(2) 鉱石処理（図 2)

a. 破碎・摩鉱 粗鉱鉱舎からフィーダで抜き出した 鉱石は, シングルトッグルクラッシャで1次破砕し, こ れを振動スクリーンでふるい分ける。網上はコーンクラ ッシャで 2 次破碎し, 網下とともに細粒鉱舎に貯える。 細粒鉱舎から抜き出した鉱石は, ボールミルとサイク ロンの閉回路で 65 mesh 以下に粉碎し, サイクロンオー バフローはさらにサイクロンで濃縮し, ドラムフィルタ で脱水してセグレゲーション原鉱とする。

b. セグレゲーション（図3） セグレゲーション原 鉱はシャフトドライヤ(1)で気流乾燥し，2段サイクロン (2)で捕集してセグレゲーション給鉱ホッパー(5)に貯え る。ホッパーからコンスタントフィーダ(6で抜き出した 鉱石は, サイクロン 3 段で構成されるサスペンションプ レヒータ(7)89(9で予熱する。熱ガス温度は $1,100^{\circ} \mathrm{C}$ に まで達する。鉱石がプレヒータに滞留する時間は, 僅か 20〜30秒に過ぎない。予熱された鉱石は, 最下位のサイ クロン9から設定温度 $800^{\circ} \mathrm{C}$ の状態で排出する。これ に適量の食塩とコークスを加えて反応炉（ロータリーキ ルン) (111に投入しセグレゲーション反応を起こさせる。 反応は約 20 分間で完了する。反応师から出た鉱石は直ち

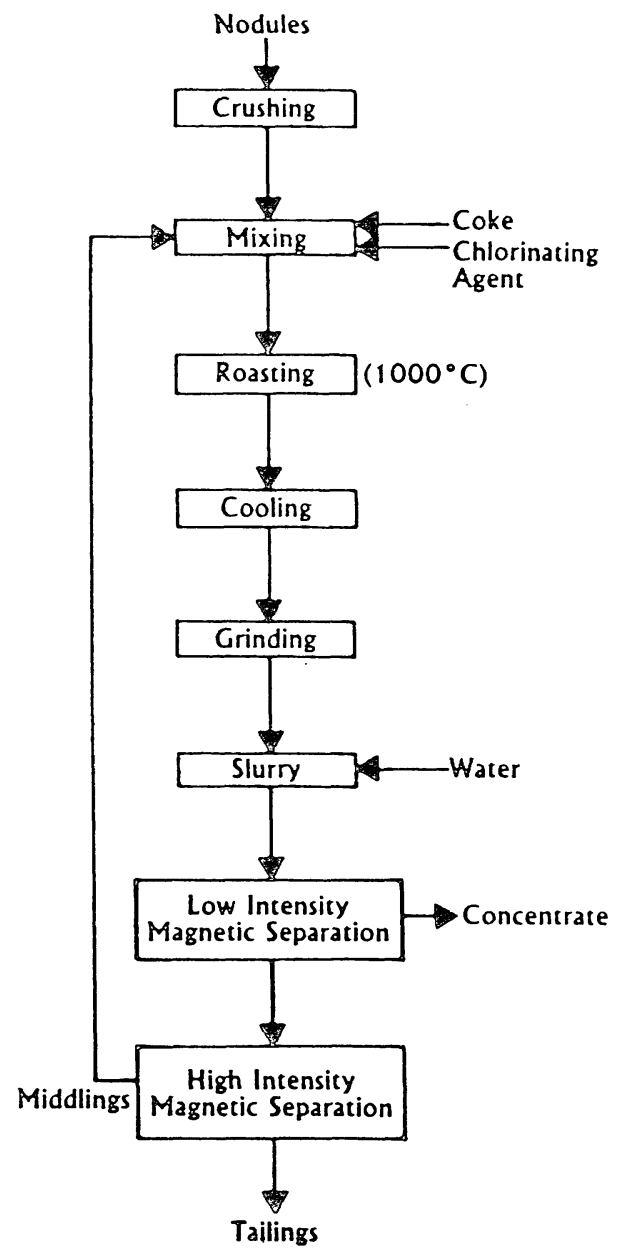

図 6 実験室規模での鉱石処理系統図 (Parekh ら ${ }^{14)}$ にる)

に水で急冷し，次いでカローューンおよびシックナで濃 縮する。

c. 浮選 カローコーンとシックナのアンダフローは コンディショナを経て浮選回路に送る。コークスの表面 に沈積した金属銅の浮選は, カリウムアミルザンセート (KAX), パイン油， Z-200 などを用い， $\mathrm{pH}$ 約 $10^{\mathrm{a})}$ の条 件で行なら。浮選機はデンバーサブ A21 番型である。 精鉱フロスはドラムフィルタで脱水し, 袋詰して出荷する。 （3）操業成績（1981年実績） 工場処理能力 $150 \mathrm{t} /$ 日。 原鉱品位 $4.15 \% \mathrm{Cu}$ ，七グレ精鉱品位 $42.9 \% \mathrm{Cu}, \mathrm{Cu}$ 実収 率 $89.6 \%$ 。主要原単位は食塩 $4.38 \mathrm{~kg} / \mathrm{t}$, コークス 20.8 $\mathrm{kg} / \mathrm{t}, \mathrm{KAX} 230 \mathrm{~g} / \mathrm{t}$, パイン油 $150 \mathrm{~g} / \mathrm{t}, \mathrm{Z}-20054 \mathrm{~g} / \mathrm{t}$, 燃料 （軽油） $12.29 \mathrm{gal} / \mathrm{t}$, 電力 $9.48 \mathrm{kWh} / \mathrm{t}$ などである。

a) 石灰質脈石の影響下での自然 $\mathrm{pH}$. 


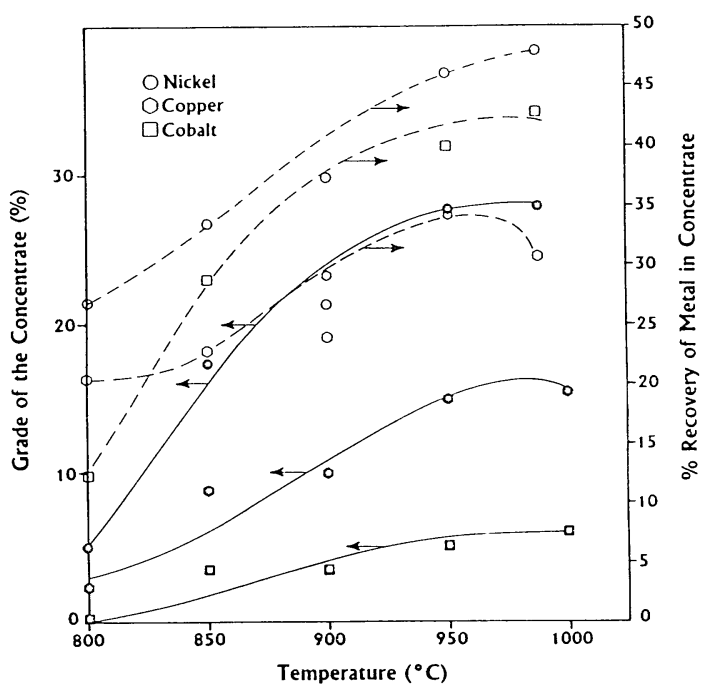

図 7 セグレゲーション温度が磁選成績におよぼす影響 (Parekh ら ${ }^{14)}$ による)

\section{4. 酸化ニッケル鉱のセグレゲーション}

\section{1 研究の経過3,19)}

ニッケル鈗石をセグレゲーション処理することの可能 性は, 1958年に米国コロンビア大学研究生の Carlos Diaz によって明らかにされた。そしてこの方法は1966 年から83年にかけ，日本，ユーゴスラビア，米国，南ア 連邦，フランス，スウェーデンなどで研究された。

銅に比ベニッケルの場合は, 遵守すべき条件が一層厳 しく制約されている。 $1,000^{\circ} \mathrm{C}$ といら高温が要求され, また $\mathrm{NaCl} 0.1 〜 1.0 \%$ の代わりにより多量の $\mathrm{CaCl}_{2}$ （鉱 石当たり 4〜7\%）が必要となる。これは塩化ニッケルガ スの加水分解を妨げるため, セグレゲーション室内を高 い $\mathrm{HCl}: \mathrm{H}_{2} \mathrm{O}$ 比に保つ必要があるからである。銅の場 合, 塩化銅ガスは加水分解に鋭敏でなく，ガス内にほん の僅かの塩化水素があるだけで十分である。珪酸質鉱石 の場合, セグレゲートされたニッケルは磁選で容易に回 収されるが，褐鉄鉱質鉱石の場合は，セグレゲーション 後にかなりの量の磁鉄鉱が存在することもあるので, 浮 選によるニッケルの回収が必要となる場合もある。

反応は吸熱的であり, セグレゲーション反応炉が単な る断熱体であることは，銅に対してはそれで十分だが， ニッヶルに対しては不十分であり熱が適切に供給される 必要がある。Le Nickel 社および AMAX 社のために Minerais et Métaux 社研究所は, セグレゲーション反応 の初めから終りまでに発生するガス分析をしつつ, 化学 反応の詳細な検討を行なった。得られた結果は非常に興 味深いものであった。

一つの重要な研究プロジェクトが Hanna Mining 社に

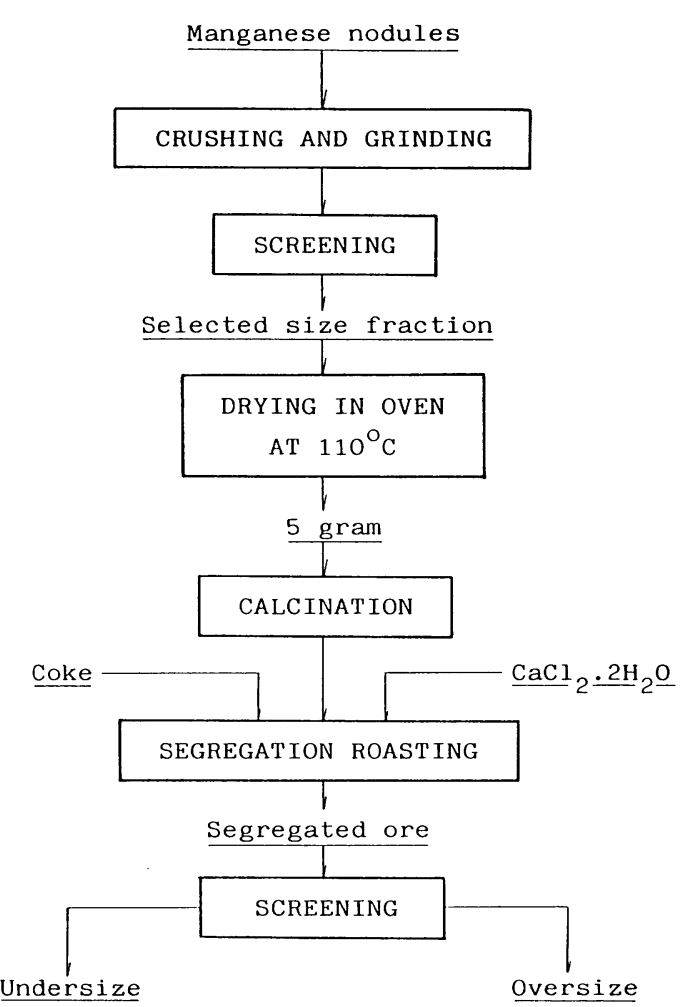

図 8 乾燥, 仮焼，セグレゲーション等の実験系統図

より実施され，薬品として炭素および塩化カルシウムの 代りに金属鉄と塩化第 1 鉄が用いられた。日本では三井 金属鉱業が，1 t/日および $10 \mathrm{t} /$ 日 処理のロータリーキル ンを用いて試験操業を行なった。ニッケル鉱石のセグレ ゲーションに関する総合討論が，1972年 2 月, Abraham A. Dor および AIME の The Metallurgical Society の主催 によって行なわれた。この問題についての詳細な文献研

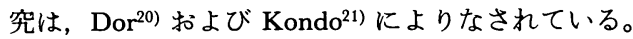

スウェーデンの Svensson が発明したメカニカルキル ンと称するセグレゲーション反応炉はボールミル形式の ものであり, 経済性に優れ試験操業にも成功している ${ }^{9,10)}$ 。 この方式の詳細を次節に述べる。

\subsection{MINPRO-PAMCO 法による試験操業9,10)}

(1) 概説 MINPRO はスウェーデンのェンジニアリン グ会社であり，PAMCO は日本の太平洋金属（株）の 英文名 Pacific Metals Co. の略称である。従って本法は 両社の協力により開発されたものである。本法の最大の 特徵は, セグレゲーション反応を行なわせるメカニカル キルンにある。10年間にわたる基礎研究を土台にパイロ ットプラントを建設し，1981年～83年の間成功裡に操業 を続けた。

（2）メカニカルキルン（表 1 および図 4）装置的には, ボールミルに耐火および断熱眯瓦を内張りし，外部の雾 

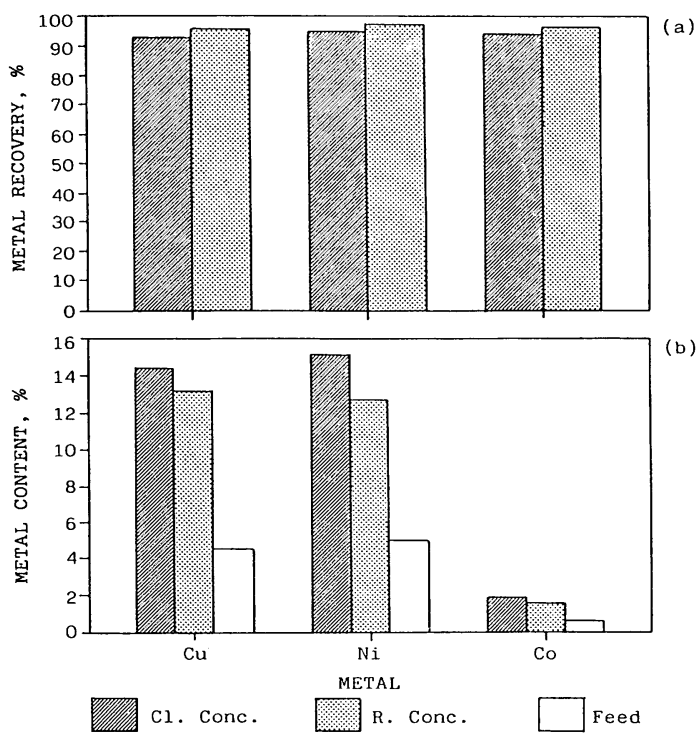

図 9 磁選における精選の効果

囲気と遮断するようシーリング装置を工夫したものであ る。ボールミルを駆動すると, 駆動モータの負荷電力量 の85９0\%は熱として損失されることが知られている。 そこでボールミルに耐火および断熱枯瓦を内張りし，こ の熱を蓄積することによってミルの炉内温度を高温に保 つことができるといら考えが，メカニカルキルンの基本 原理となっている。用いられたボールミルの機種は自生 粉砕機で, 粉砕媒体はアルミナボールである。

\section{(3) 試験操業}

a. 鉱石の化学成分 使用した鉱石は，フィリピン Palawan 島 Rio Tuba 鉱山産の酸化ニッケル鉱である。 鉱石の化学成分 (\%) の一例を示すと, Ni 2.30, Fe 13.21, Co 0.04, Cr 0.70, Mn 0.26, P 0.0014, S 0.029, $\mathrm{SiO}_{2} 42.6$, $\mathrm{MgO} 22.6, \mathrm{CaO} 0.2, \mathrm{Al}_{2} \mathrm{O}_{3} 0.8$, 水分28.0である。

b. 乾燥, 仮焼 鉱石は重油燃焼ロータリーキルン内 で, 水分 $18 \%$ 程度になるまで乾燥される。仮焼炉部分で は，鉱石を加熱するため軽油を $75 \mathrm{l} / \mathrm{t}$ の割合で用いる。 水分 $18 \%$ の乾燥鉱 $1 \mathrm{t}$ から, $760 \mathrm{~kg}$ の仮焼産物が得られ る。仮焼炉内の温度は $950^{\circ} \mathrm{C}$ に保持する。

c. セグレゲーション スクリューフィーダにより仮 焼産物，塩化カルシウムおよびュークブリーズをメカニ カルキルンに供給する。仮焼産物 $760 \mathrm{~kg}$ 当り, 塩化カ ルシウム $40 \mathrm{~kg}$, ニークス $20 \mathrm{~kg}$ を添加する。

添加剂の量は厳密に規制する必要がある。炭素分の過 唾は固相還元には有利であるが，ニッケル実収率の実質 的低下をもたらす。水分の過㮃は，同様の影響を伴う塩 化物の加水分解を招く。塩化物の過㮃は固体の流れや適 切な排出を妨げる。このように， G-H-O-Cl 間のバラン
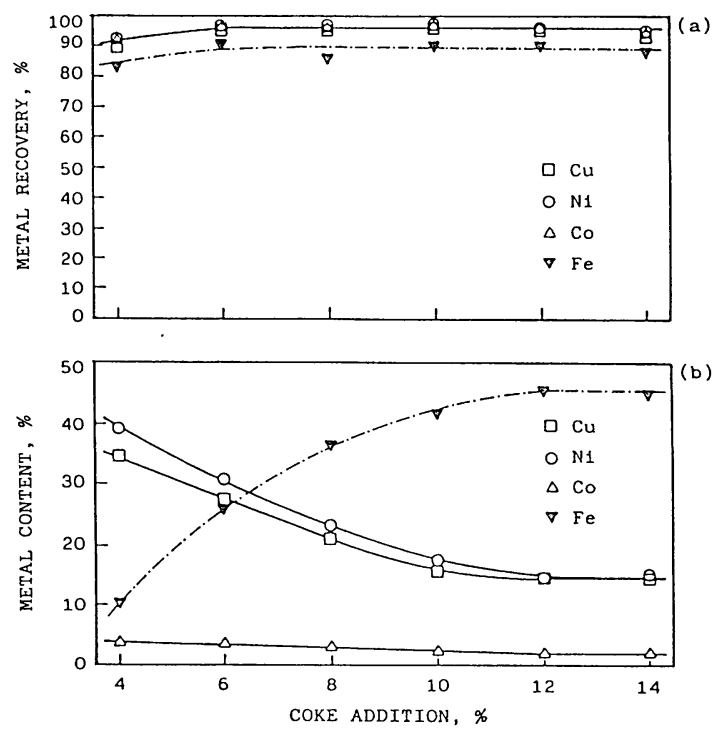

図10 セグレゲーションでのコークス添加率が磁選成 績におよぽす影響（精選）

スを保つことが重要である。

反応過程において，3 価の $\mathrm{Fe}$ のすべてが還元される と, 極端に色が変わる。すべての $\mathrm{FeO}$ は珪酸塩中に固 定される。

セグレゲーション産物は, マルチュイルクーラで外気 と遮断しながら $100^{\circ} \mathrm{C}$ まで冷却し，大気中に排出する。

d. 磁選 セグレゲーション後冷却した産物は水でス ラリー化させ, ボールミルで粉砕後磁選機へフィードす る。磁選機はドラム型低磁場磁選機 2 段処理を基本系統 とし, 必要に応じドラム型磁選機の尾鉱を Jones 高磁場 磁選機で処理する。磁選成績の 1 例を表 2 に示す。表 2 に示されるよらに，ドラム型と Jones 磁選機の精鉱を合 わせれば， $\mathrm{Ni}$ 実収率は $90 \%$ 以上となる。

e. エネルギー消費 本法の場合の鉱石加熱温度は約 $950^{\circ} \mathrm{C}$ であり, 電気炉や溶鉱炬の加熱温度が約 $1,600^{\circ} \mathrm{C}$ であることに比べると,エネルギーが大幅に節約できる。 工業化の場合の電力原単位は, 乾燥鉱 $1 \mathrm{t}$ 当り $150 \mathrm{kWh}$ と想定されている。

(4) 工業化のために提案された操業系統図図 5 に示 す。

\section{5. マンガンノジュールのセグレゲーション}

\section{1 研究の眚向}

マンガンノジュール（以下ノジュールと略記する）は， 深海の堆積層上に存在する丸味を帯びた暗褐色塊状の鉱 物集合体で，20〜30\%の Mn，5２0\%の Fe，合わせて 1〜3\%の $\mathrm{Cu}, \mathrm{Ni}$ および Co を含有する。これらを資源 として活用することには多くの国で関心がもたれ，採鉱 
から製錬にいたるより安価で有効な技術の探究が現在続 けられている。

資源的価值からみると，ノジュール中の元素のうち， $\mathrm{Cu}, \mathrm{Ni}$ 拉よびCoがとくに注目される。これらを金属と して回収する工程に選鉱操作が組み入れられれば，それ に応じたコスト低隇が期待できる。しかしこれら 3 元素 は, $\mathrm{Mn}$ や $\mathrm{Fe}$ の化合物中に固溶成分として存在するた め, ノジュールを直接選鉱処理することによって各元素 を効果的に濃縮するのは困難である。この問題を解決す るため, ノジュールにセグレゲーション法を適用し，そ の産物を何らかの選鉱法で処理することが，過去いく人 かの研究者により試みられている11 15,22 24)。

本稿では, 最も最近行なわれた二つの研究の成果の要 点を紹介する。

5.2 ケンタッキー大学 Parekh, Jepsen およよび Goldberger らの研究 ${ }^{14}$

(1) 試料扣よび実験方法 実験に使用したノジュール の化学分析值 (\%)は, Ni 1.33, Cu 1.14, Co 0.21, Fe 5.81 である。鉱石処理系統図を図 6 亿示す。

セグレゲーションに用いた炬は電気管状炬である。，

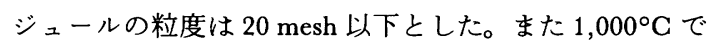
の保持時間は60分とした。高磁場磁選の着磁産物はミド リングであるが，これはフィードに混ぜて再処理する方 法をとった。ミドリングの化学分析值 (\%) は, Ni 2.02, $\mathrm{Cu}$ 1.27, Co 0.31, Fe 6.22 である。

(2) 実験結果および考察の要点

a. 温度の影響（図 7） 効果的焙焼温度は $900^{\circ} \mathrm{C}$ 以 上であり， $850^{\circ} \mathrm{C}$ 以下になるとその効果は急激に減退す る。

b. 塩化剤の影響（表 3） $\mathrm{CaCO}_{3}-\mathrm{NaCl}, \mathrm{Ca}(\mathrm{OH})_{2}$ $\mathrm{NaCl}$ および $\mathrm{CaCl}_{2}$ が最適塩化剤と認められる。ただし, $\mathrm{CaCl}_{2}$ を用いた場合（試験 $\mathrm{C}$ ), 尾鉱中への金属の逃失 がかなり高かった。そこで本研究では, $\mathrm{CaCO}_{3}-\mathrm{NaCl}$ ま たは $\mathrm{Ca}(\mathrm{OH})_{2}-\mathrm{NaCl}$ の組合せを以後の研究に用いること とした。

c. ミドリングの綝返しの効果 ミドリングを $50 \%$ 混 合した場合, 最良の結果が得られた。この場合, 精鉱品 位として $35 \% \mathrm{Ni}, 24 \% \mathrm{Cu}$ が期待できる。ただし，Coは $3 \%$ $3 \%$ とまる。また，精鉱とミドリングを合わせた総 合金属実收率は $80 \%$ 以上となる。精鉱中の $\mathrm{Ni}, \mathrm{Cu}$ 打よ び Coは, $\mathrm{Fe}$ との合金の形で存在する。

\section{3 篟者らの研究 13,15$)$}

(1) 試料および実験方法 実験に供したノジュールは, 東太平洋中部地域で第二白嶺丸により採取されたもので あり, その化学分析值 (\%) は, Ni 1.42, Cu 1.25, Co 0.29, Mn 30.56, Fe 5.41 である。

試料は磁製乳鉢で $150 \mu \mathrm{m}$ 以下に粉砕し，これをさら
に所定粒度にふるい分け, $110^{\circ} \mathrm{C} に て$ 乾燥後実験に使用 した。

ノジュールは結晶水が多いため, 系内の水素分圧が過 剩となってセグレゲーションでない直接還元が起こる可 能性が高い。そこでまず仮焼条件の検討を行なった。次 いでセグレゲーション条件の検討を行なった。セグレ ゲーション産物は $212 \mu \mathrm{m}$ でふるい分け，それぞれに対 する浮選試験および磁選試験を実施し，それらの成績を 比較検討した。

乾燥, 仮焼, セグレゲーション等の実験系統図を図 8 に示す。仮焼には電気マッフル炉を，セグレゲーション には電気管状炉を使用した。また浮選にはガラス浮選機 と小型 MS-浮選機を, 磁選には Eriez 湿式高磁力選鉱機 （L-4 型）を用いた。

(2) 実験結果および考察の要点

a. 仮焼 最適条件は，温度 $950^{\circ} \mathrm{C}$, 時間30分であっだ。

b. 七グレゲーション $\mathrm{NaCl}, \mathrm{CaCl}_{2} \cdot 2 \mathrm{H}_{2} \mathrm{O}, \mathrm{AlCl}_{3}$ の 3 種の塩化剂を比較した結果では, $\mathrm{CaCl}_{2} \cdot 2 \mathrm{H}_{2} \mathrm{O}$ が最 も有効であった。その他最良の効果が得られた条件を列 記すると以下のようである。婄焼温度 $900^{\circ} \mathrm{C}$, 時間 120 分, ノジュール粒度 $53 \sim 75 \mu \mathrm{m}, コ ー ク ス$ 粒度 $300 \sim 425 \mu \mathrm{m}, \mathrm{CaCl}_{2} \cdot 2 \mathrm{H}_{2} \mathrm{O}$ 添加率 $26 \%$ a)。

c. 浮選および磁選結果の比皎 表 4 亿示す。なお， この際の実験条件は次のようである。

$+212 \mu \mathrm{m}$ 粒群（粗選のみ）

浮選: 浮選粒度 $-38 \mu \mathrm{m}, \mathrm{pH} 7, \mathrm{MIBC}$ 添加 3.7 $\mathrm{kg} / \mathrm{t}$ 。

磁選：磁選粒度 $-38 \mu \mathrm{m}$, 磁束密度 $6,200 \mathrm{G}$ 。

$-212 \mu \mathrm{m}$ 粒群（粗選のみ）

浮選: 浮選粒度 $-212 \mu \mathrm{m}, \mathrm{pH} \mathrm{7.8,} \mathrm{カリウムアミル}$ ザンセート $1.25 \mathrm{~kg} / \mathrm{t}, \mathrm{CuSO}_{4} 2.5 \mathrm{~kg} / \mathrm{t}, \mathrm{MIBC} 0.54 \mathrm{~kg} / \mathrm{t}$

磁選 : 自動メノウ乳鉢で20分粉碎したものをフィー ドとした。磁束密度 $7,200 \mathrm{G}_{\text {。 }}$

表 4 に示されるよらに, 浮選, 磁選とも $+212 \mu \mathrm{m}$ 粒 群の選別成績のほうが優れている。ただし $+212 \mu \mathrm{m}$ に ついては，金属と炭素との分離b が目的で, $-212 \mu \mathrm{m}$ については, 脈石中で還元された金属の濃縮が目的で浮 選, 磁選が行なわれた。+212 $\mu \mathrm{m}$ の浮選と磁選を比較 すると, 後者の成績のほうがはるかに優れていることが わかる。

d. 好成績を得るために留意すべき点 1) 炭素上に 析出した金属と炭素との単体分離を十分ならしめるた め, セグレゲーション産物の $+212 \mu \mathrm{m}$ 粒群は, 選別操

a)酸化銅鉱や酸化ニッケル鉱に比べ塩化剂の使用量が大 となる原因は, 多量の $\mathrm{MnO}$ により塩化忶が消費され てしをらためと解秎される。

b) 浮選では炭素を浮かせる。 
作の前に粉碎する必要がある。 $-300 \mu \mathrm{m},-150 \mu \mathrm{m}$, $-75 \mu \mathrm{m},-38 \mu \mathrm{m}$ の 4 種に粉砕して磁選成績を比較し た例では, $-38 \mu \mathrm{m}$ の成績が最も良好であった。

2）選別に際し，精選は有効である。粗選を 6,200 G, 精選を 4,300 G で行なった際の磁選成績を図 9 に示す。 精選を行ならことにより，Cu品位は $12.23 \%$ から $14.27 \%$, Ni 品位は $12.81 \%$ から $15.22 \%$, Co 品位は $1.60 \%$ から $1.89 \%$ へと上昇する。この実験は，精選尾鉱 を粗選フィードに繰返す操作を入れて行なった。

3）セグレゲーション段階でコークス添加率を増やす と磁選実収率は僅か向上するものの, 精鉱品位は著しく 低下寸る。これは図10に反映されているように，セグレ ゲーション産物中の金属鉄含有率が増えるためである。 従って, 眓の範囲ではコークス添加率は少ないほどよい と判断される。もしコークス添加率を $4 \%$ とすれば， $\mathrm{Cu}, \mathrm{Ni}$ の精選精鉱品位はともに $30 \%$ 以上となる。そし て実收率子 $90 \%$ 前後を保つ。

\section{6.むすび}

セグレゲーション法の展望と題し，1）セグレゲーシ ョンの反応機構（塩化水素ガスの発生, 金属成分の塩化 および金属塩化物の蒸発, 炭素表面上への金属相の析出,

2）酸化銅鉱のセグレゲーション（発展の経過, ペルー Katanga 鉱山に扩ける操業の実際)，3）酸化ニッヶル鉱 のセグレゲーション（研究の経過, MINPRO-PAMCO 法による試験操業)，4）マンガノジュールのセグレゲー ション（研究の動向, ケンタッキー大学 Parekh, Jepsen および Goldberger らの研究, 筆者らの研究) などにつ き概要を述べた。

セグレゲーション法は，そのままでは通常の選鉣技術 が適用しにくい鉱石のうち, 揮発性塩化物またはオキシ 塩化物を形成する金属を含むものの処理に適する。酸化 銅鉱, 酸化二ッケル鉱, マンガンノジュール等へのセグ レゲーション法の適用技術がさらに発展するとともに,

$\mathrm{Sb}, \mathrm{Bi}, \mathrm{Au}, \mathrm{Ag}, \mathrm{Pd}, \mathrm{Sn}$ 等のレアメタルを含有する鉱石へ の本法適用の可能性の探究む期待されるところである。

\section{参考文 献}

1) JIS 鉱山用語 M 0102 (1978) p. 63

2) 今泉常正：セグレゲーション・プロセスについて, 浮選, No. 17 (1962) p. 1 8

3) Iwasaki, I.: A Thermodynamic Interpretation of the Segregation Process for Copper and Nickel Ores, Minerals Sci. Engng., Vol. 4, No. 2 (1972) p. 14 23

4）山口武晴: ヘルー, カタンガ鉱山の酸化銅鉱の処理 について, 日本鉱業会秋季大会分科研究会資料, G-4 (1974) p. 1 4

5) Kaneko, M.: Mitsui Segregation Process Treats Peruvian Copper Oxides, E/MJ, Dec. (1974) p. $61 \sim 64$
6）山口武晴, 中尾正英, 松井暢夫, 保坂秀人：酸化銅 釷の処理について (第 1 報), 浮選, Vol. 28, No. 3 (1981) p. $141 \sim 148$

7）有田義正：カタンガ, セグレゲーション選鉱工場, 日本鉱業会誌, Vol. 98, No. 1134 (1982) p. 869 871

8) Svensson, J.: US Patent No. 3,929,463 (1975)

9）石井小太郎：酸化ニッケル鉱石のセグリゲーション 焙焼法について, 日本鉱業会誌, Vol. 101, No. 1169 (1985) p. $433 \sim 436$

10) Ericson, A. S., Svensson, J. and Ishii, K.: The MINPRO-PAMCO Nickel Segregation Process, Int. J. Miner. Process., Vol. 19 (1987) p. 223 236

11) Hoover, M., Han, K. N. and Fuerstenau, D. W.: Segregation Roasting of Nickel, Copper and Cobalt from Deep-sea Manganese Nodules, Int. J. Miner. Process., Vol. 2 (1975) 173 185

.12）朝倉岩三, 真保良吉, 小川 修, 後藤佐吉 : ノジュルに対するセグリゲーション法の応用（藤井雄二郎 編：マンガンノジュールの処理技術一その後の進 展), 日本鉱業会誌, Vol. 102, No. 1186 (1986) p 836 $\sim 837$

13）Djohari, A., 大和田秀二, 原田種臣, 後藤佐吉 : ソガンノジュールのセグレゲーションにおける焙焼 条件の検討一七グレゲーション法によるマンガン， ジュールからの $\mathrm{Cu}, \mathrm{Ni}$ および Co の回収(第 1 報), 日本鉱業会誌, Vol. 104, 1207 (1988年) p. 615 620

14) Parekh, B. K., Jepsen, T. L. B. and Goldberger, W. M.: Segregation Roasting and Beneficiation of Deep Sea Nodules, Marine Mining, Vol. 7 (1988) p. $417 \sim 429$

15) Djohari, A., Owada, S., Harada, T. and Goto, S.: Application of the Segregation Process to Manganese Nodules, Proceedings of MMIJ/IMM Joint Symposium (Today's Technology for the Mining and Metallurgical Industries), Kyoto (1989) p. 359 371

16) Rey, M.: Le Procédé de Ségrégation des Minerais de Cuivre Oxydés Pauvres, VII e Congrès International des Mines, de la Métallurgie et de la Géologie Appliquée, Paris, Section de Métallurgie, Vol. 2, No. 3 (1935) p. $55 \sim 62$

17) Kellogg, H. H.: Thermodynamic Relationships in Chlorine metallurgy, Trans. Am. Inst. Min. Engrs., Vol. 188 (1950) p. 862 872

18）三村晴夫, 今井 直, 菅原泰造, 鈴木隆三 : 珪ニッ ケル鉱のセグレゲーション法に関する基礎的研究, 日本鉱業会誌, Vol. 82, No. 938 (1966) p. 514 518

19) Rey, M.: Memoirs of Milling and Process Metallurgy (4) $\cdots$ Segregation Processes, Trans. Instn. Min. Metall. (Sect. C: Mineral Process. Extr. Metall.), Vol. 89, Sep (1980) p. C101 C107

20) Dor, A. A.: Nickel Segregation Symposium at $101 \mathrm{st}$ Annual Meeting of AIME, San Francisco (1972)

21) Kondo, Y.: Segregation Process for Lateritic Nickel Ores, The Mining and Metallurgical Institute of Japan 90th Anniversary Number (1975)

22) Grigor'yeva, V. M. and Ogorodnikova, L. A.: Extraction of Nickel, Copper and Cobalt from Ironmanganese Concretions by the Segregation Method, Isvetnyye Metally, Vol. 9 (1972) p. 19 23

23) Sridhar, R.: Thermal Upgrading of Sea Nodules, J of Metals, Vol. 26 (1974) p. 18 27

24) Beil, M. C. E. and Sridhar, R.: Dressing of Manganese Nodules, German Patent No. 2,438, 773 (1975) 